\title{
Peningkatan Produktivitas Padi Gogo (Oryza Sativa Linnaeus) Akibat Aplikasi Pupuk Urea Dan Bakteri Pemfiksasi Nitrogen Dalam Bahan Pembawa Pada Inceptisols Asal Jatinangor
}

\section{Fadhilla Oktavianingtyas Trisilvi ${ }^{1}$, Nadia Nuraniya Kamaluddin², Betty Natalie Fitriatin ${ }^{2}$ Diyan Herdiyantoro ${ }^{2}$, dan Pujawati Suryatmana ${ }^{2}$ \\ 1Mahasiswa Program Studi Agroteknologi Fakultas Pertanian Universitas Padjadjaran ${ }^{2}$ Staff Pengajar Departemen Ilmu Tanah dan Sumber daya Lahan Fakultas Pertanian UNPAD \\ Jl. Raya Bandung Sumedang Km 21 Jatinangor \\ Korespondensi:Fadhilla17002@mail.unpad.ac.id}

\begin{abstract}
As a staple in Indonesian diet, rice demand increase along with the population growth. Therefore, in order to fulfill the continuous increase, researches were conducted to increase land productivity. The increase of growth and productivity of upland rice with the application of Azospirillum sp. and Azotobacter sp. in compost, Azolla, and rice bran carrier were studied. Nitrogen fixer were applied as a biofertiliser as a mean to supply available nitrogen for upland rice growth. This research was conducted in Ciparanje Experimental Field and Soil Biology Laboratory, Faculty of Agriculture, Universitas Padjadjaran. In this research, Randomized Block Design was used to analyze two factors: urea dose (100\% and 50\%) and Nfixer bacteria in various carriers (individual carrier and combination of liquid inoculant, green compost, Azolla compost, rice bran). The result showed an interaction between two factors towards the grain weight of upland rice. The application of $100 \%$ urea dose showed higher result compared to 50\% urea dose on grain weight. $N$ fixer bacteria combined with compost, Azolla, and rice bran carrier gave the highest result on the number of tillers, chlorophyll content, and grain weight.
\end{abstract}

Keywords: Azospirillum sp., Azotobacter sp., Urea fertilizer, grains weight, compost, Azolla, rice bran, chlorophyll, panicles

\section{PENDAHULUAN}

Penduduk Indonesia yang semakin meningkat berbanding lurus dengan kebutuhan pangan masyarakat Indonesia dan kebutuhan masyarakat Indonesia akan beras yang merupakan makanan pokok. Badan Pusat Statistik (BPS) memprediksi pada tahun 2019 konsumsi beras per kapita per tahun mencapai 97,05 kg (PUSDATIN, 2019). Upaya untuk memenuhi kebutuhan beras di Indonesia adalah dengan menanam padi gogo yang merupakan tanaman padi yang ditanam di lahan kering. Penanaman padi gogo dapat memanfaatkan lahan kering yang terhampar luas di Indonesia.

Peningkatan hasil tanaman padi gogo dapat dilakukan dengan menggunakan varietas unggulan dan pemberian pupuk dengan dosis yang seimbang (Sirappa dan Waas, 2009). Unsur hara $\mathrm{N}$ memiliki peran penting dalam pertumbuhan vegetatif yaitu sebagai bahan penyusun protein dan lemak dan sebagai bahan penyusun klorofil daun sehingga tanaman berwarna lebih hijau (Setyamidjaja, 1986). Pemenuhan unsur hara $N$ pada tanaman sering kali digunakan pupuk Urea, namun pemakaian pupuk Urea yang berlebihan dapat berdampak buruk bagi tanaman.

Supriyo dkk. (2014) menyatakan bahwa penggunaan pupuk hayati dengan $50 \%$ pupuk NPK rekomendasi pada penanaman padi gogo dapat mengimbangi hasil pemupukan 100\% pupuk NPK rekomendasi. Bakteri pemfiksasi N non simbiotik yang digunakan pada penelitian ini adalah Azospirillum sp. dan Azotobacter sp. Bakteri Azospirillum dan Azotobacter yang tergolong dalam Plant Growth Promoting Rhizobacteria (PGPR). Plant Growth Promoting Rhizobacteria memiliki peran ganda yaitu: Menambat N2, menghasilkan hormon tumbuh, menekan penyakit tanaman asal tanah, dan dapat melarutkan unsur hara P dan unsur hara lainnya (Cattelan et. al., 1999; Glick dkk., 1995; Kloepper, 1993; Kloepper dkk., 1991). 
Pada penelitian ini digunakan Azolla, dedak, dan kompos sebagai bahan pembawa untuk menjaga viabilitas bakteri. Azolla pinnata adalah tanaman paku-pakuan air yang dapat menyebar dengan sangat cepat. Azolla pinnata sebagai bahan pembawa bakteri Azotobacter sp., Azospirillum sp., Endofitik, dan BPF berpengaruh nyata terhadap meningkatnya kandungan $\mathrm{N}$-total sebesar 3,26\% N (Setiawati dkk., 2017).

Dedak merupakan hasil sampingan atau limbah proses penggilingan gabah dan penyosohan beras. Berdasarkan penelitian mengenai uji bahan pembawa dedak padi dan tepung tapioka pada bakteri pelarut fosfat menunjukkan bahan pembawa dedak padi memiliki kemampuan yang lebih baik dibandingkan bahan pembawa tepung tapioka (Ahmad dkk., 2015).

Kompos yang merupakan hasil dekomposisi bahan organik oleh mikroorganisme dekomposer berpotensi dijadikan bahan pembawa pupuk hayati. Kompos yang diperkaya dengan pupuk hayati yang terdiri atas 7 isolat bakteri dapat meningkatkan komponen produksi pada tanaman padi sawah dan gogo (Aryanto dkk., 2015).

Jumakir dan Endrizal (2019) menyatakan bahwa penggunaan pupuk hayati pada penanaman padi sawah berperan dalam peningkatan komponen hasil dan pertumbuhan tanaman serta mengurangi penggunaan pupuk NPK rekomendasi hingga 50\%. Penggunaan pupuk Urea dapat mengalami pengurangan karena adanya bakteri pemfiksasi nitrogen yang mampu menyediakan unsur hara $\mathrm{N}$ pada tanaman. Hal ini berkaitan dengan pernyataan Arjjumend (2006) bahwa Rizobakteri Azospirillum dan Azotobacter dapat menambat $\mathrm{N}_{2}$ setara dengan 20-40 $\mathrm{kg} \mathrm{N} /$ ha sekaligus memproduksi hormon. Oleh karena itu, diharapkan penggunaan pupuk hayati dalam carrier pada penelitian ini dapat mengurangi penggunaan dosis NPK hingga 50\%.

\section{METODOLOGI}

Penelitian ini dilaksanakan pada bulan November 2020 hingga Juni 2021 yang bertempat di Rumah Kaca Lahan Percobaan Ciparanje, Fakultas Pertanian, Universitas Padjadjaran. Pembuatan biakan pupuk hayati dilakukan di Laboratorium Biologi Tanah, Fakultas Pertanian, Universitas Padjadjaran.

\subsection{Rancangan Percobaan}

Rancangan yang digunakan untuk penelitian ini adalah Rancangan Acak Kelompok (RAK) Faktorial dengan faktor I yaitu dosis pupuk Urea taraf $100 \%$ dan $50 \%$ dan faktor II Bakteri Pemfiksasi N (BPN) dalam bahan pembawa kompos, Azolla, dan dedak. Penelitian ini menggunakan padi gogo varietas Situ Bagendit yang ditanam pada 48 polybag dengan parameter jumlah anakan, kandungan klorofil, dan bobot Gabah Kering Panen (GKP) per polybag. Hasil penelitian dianalisis secara statistika menggunakan aplikasi SPSS.

Perlakuan pada penelitian ini terdiri dari faktor I dosis Urea yaitu:

$\mathrm{a}^{1}: 100 \%$ dosis Urea sebanyak $300 \mathrm{~kg} \mathrm{Ha}^{-1}$ $\mathrm{a}^{2}: 50 \%$ dosis Urea sebanyak $150 \mathrm{~kg} \mathrm{Ha}^{-1}$

Faktor II adalah bakteri pemfiksasi N (BPN) dalam Carrier, yang terdiri atas 7 perlakuan, yaitu:

$\mathrm{b}_{0}$ : bakteri pemfiksasi $\mathrm{N}$ kultur cair

$\mathrm{b}_{1}$ : bakteri pemfiksasi $\mathrm{N}$ dalam carrier kompos

$\mathrm{b}_{2}$ : bakteri pemfiksasi $\mathrm{N}$ dalam carrier azolla

$\mathrm{b}_{3}$ : bakteri pemfiksasi $\mathrm{N}$ dalam carrier dedak

$\mathrm{b}_{4}$ : bakteri pemfiksasi $\mathrm{N}$ dalam carrier kompos + azolla

$\mathrm{b}_{5}$ : bakteri pemfiksasi $\mathrm{N}$ dalam carrier kompos + dedak

$\mathrm{b}_{6}$ : bakteri pemfiksasi $\mathrm{N}$ dalam carrier dedak + azolla

$\mathrm{b}_{7}$ : bakteri pemfiksasi $\mathrm{N}$ dalam carrier kompos + dedak + azolla.

Jumlah kombinasi perlakuan 16 yang akan diulang sebanyak 3 kali, sehingga total satuan percobaan adalah 48 . 


\subsection{Rancangan Perlakuan}

Pupuk hayati yang digunakan $50 \mathrm{~kg} \mathrm{Ha}^{-1}$, konsorsium Azotobacter dan Azospirillum yang diberikan pada carrier adalah $10 \mathrm{ml}$ untuk pembuatan $100 \mathrm{gr}$ formula pupuk hayati. Kepadatan bakteri pemfiksasi N Azotobacter sp. dan Azospirillum sp. dalam media cair adalah $10^{10} \mathrm{CFU} \mathrm{g}^{-1}$. Bakteri pemfiksasi $\mathrm{N}$ diencerkan menggunakan carrier sebanyak 100 kali untuk mencapai konsentrasi $10^{8} \mathrm{CFU}$ $\mathrm{g}^{-1}$ sementara pada perlakuan kultur cair, BPN diencerkan dengan $\mathrm{NaCl}$ fisiologis. Pupuk hayati diaplikasikan pada lubang tanam ketika penanaman berlangsung.

Pupuk Urea yang digunakan $300 \mathrm{~kg} \mathrm{ha}^{-1}$ atau $1,5 \mathrm{~g}$ per pot dosis anjuran $100 \%$ dan 150 $\mathrm{kg} \mathrm{Ha}^{-1}$ atau $0,75 \mathrm{~g}$ per pot dosis anjuran $50 \%$. Pupuk Urea diaplikasikan ketika 7 Hari Setelah Tanam (HST), 21 HST, dan 42 HST. Untuk memenuhi kebutuhan unsur hara $\mathrm{P}$ dan $\mathrm{K}$ digunakan pupuk $\mathrm{KCl}$ dan SP-36 dengan dosis $100 \mathrm{~kg} \mathrm{ha}^{-1}$

Formulasi pupuk hayati dilakukan dengan mencampurkan konsorsium Azotobacter dan Azospirillum sebanyak 10\% (v/w) dengan tepung tapioka, kompos, dan bahan pembawa persentasenya berbeda tiap perlakuan secara aseptik (perlakuan kultur cair tidak menggunakan carrier; perlakuan carrier kompos, Azolla, dedak menggunakan 100\% carrier; perlakuan campuran carrier kompos + Azolla, kompos + dedak, dan dedak + Azolla menggunakan $50 \%$ carrier 1 dan $50 \%$ carrier 2; dan perlakuan campuran carrier kompos, dedak, dan Azolla menggunakan perbandingan carrier 1 : carrier 2 : carrier 3 sebanyak 1:1:1)).

\section{HASIL DAN PEMBAHASAN}

\subsection{Jumlah anakan}

Hasil analisis statistika pada jumlah anakan menunjukkan tidak terdapat interaksi di antara kedua faktor. Perlakuan dosis Urea dengan hasil yang berpotensi meningkatkan jumlah anakan dengan baik terdapat pada dosis Urea $50 \%$ dengan rata-rata sebesar 22,79. Faktor BPN dalam bahan pembawa berpengaruh nyata terhadap parameter jumlah anakan. Perlakuan BPN dalam bahan pembawa kompos, dedak, dan Azolla memiliki rata-rata tertinggi yaitu 28,83.

Tabel 1 Hasil Analisis Dosis Urea dengan Pupuk Hayati Pemfiksasi N terhadap Rataan Jumlah Anakan Padi Gogo

\begin{tabular}{|c|c|}
\hline Perlakuan & Rataan \\
\hline \multicolumn{2}{|l|}{ Dosis Urea } \\
\hline$a_{1}(100 \%)$ & 22,69 \\
\hline a2 $(50 \%)$ & 22,79 \\
\hline \multicolumn{2}{|c|}{ Formula Bakteri Pemfiksasi N (BPN) } \\
\hline bo (BPN Kultur Cair) & $17,58 \mathrm{a}$ \\
\hline $\mathrm{b}_{1}(\mathrm{BPN}+$ Carrier Kompos) & $22,67 \mathrm{bc}$ \\
\hline $\mathrm{b}_{2}(\mathrm{BPN}+$ Carrier Azolla) & $23,92 \mathrm{c}$ \\
\hline $\mathrm{b}_{3}(\mathrm{BPN}+$ Carrier Dedak) & $22,50 \mathrm{bc}$ \\
\hline $\begin{array}{l}\mathrm{b}_{4} \text { (BPN + Carrier Kompos + } \\
\text { Azolla) }\end{array}$ & $22,67 \mathrm{bc}$ \\
\hline $\begin{array}{l}\text { b5 (BPN + Carrier Kompos + } \\
\text { Dedak) }\end{array}$ & $22,33 \mathrm{bc}$ \\
\hline $\begin{array}{l}\mathrm{b}_{6}(\mathrm{BPN}+\text { Carrier Dedak + } \\
\text { Azolla) }\end{array}$ & $21,42 \mathrm{~b}$ \\
\hline $\begin{array}{l}\text { b7 (BPN + Carrier Kompos + } \\
\text { Dedak + Azolla) }\end{array}$ & $28,83 \mathrm{~d}$ \\
\hline $\begin{aligned} \text { terangan: } & \text { Angka-angka yang d } \\
& \text { sama pada kolom dar } \\
& \text { yang sama tidak berb } \\
& \text { DMRT pada } \alpha=5 \% .\end{aligned}$ & $\begin{array}{l}\text { huruf } \\
\text { r perlak } \\
\text { ata pad }\end{array}$ \\
\hline
\end{tabular}

Varietas Situ Bagendit yang digunakan pada penelitian ini umumnya menghasilkan jumlah anakan 12-13 batang per rumpun. Peningkatan jumlah anakan padi gogo dari jumlah yang biasa dicapai pada Varietas Situ Bagendit diduga karena nutrisi yang didapatkan dari pupuk hayati pemfiksasi $\mathrm{N}$ dan pupuk Urea. Unsur hara $\mathrm{N}$ memiliki peran dalam pertumbuhan vegetatif dan merangsang jumlah anakan padi (Yoshida, 1981).

Perlakuan pupuk hayati pemfiksasi $\mathrm{N}$ dalam kultur cair tanpa menggunakan bahan pembawa memiliki hasil terendah dibandingkan perlakuan lainnya yang menggunakan bahan pembawa. Berdasarkan pernyataan Yoshida (1981) bahwa jumlah anakan meningkat bersamaan dengan meningkatnya kadar nitrogen hingga 5\% diduga bahan pembawa dapat meningkatkan koloni bakteri 
pemfiksasi $\mathrm{N}$ sehingga suplai unsur hara $\mathrm{N}$ pada tanaman semakin meningkat.

\subsection{Kandungan Klorofil}

Hasil uji statistika pada parameter kandungan klorofil pada tanaman padi gogo adalah tidak terdapat interaksi antara faktor dosis Urea dengan formula bakteri pemfiksasi $\mathrm{N}$ dalam bahan pembawa. Faktor dosis Urea tidak memiliki pengaruh nyata terhadap parameter kandungan klorofil sementara faktor formula pupuk hayati dalam bahan pembawa memiliki pengaruh nyata terhadap kandungan klorofil. Perlakuan BPN dalam bahan pembawa kompos, dedak, dan Azolla memiliki hasil lebih tinggi dibandingkan kontrol dengan hasil rata-rata sebesar 34,80 .

Tabel 2 Hasil Analisis Pengaruh Dosis Urea dan Pupuk Hayati Pemfiksasi N terhadap Kandungan Klorofil Padi Gogo

\begin{tabular}{|c|c|}
\hline Perlakuan & $\begin{array}{l}\text { Kandungan } \\
\text { Klorofil } \\
\left(\mathrm{mg}_{\text {.gr }}{ }^{-1}\right)\end{array}$ \\
\hline \multicolumn{2}{|l|}{ Dosis Urea } \\
\hline$a_{1}(100 \%)$ & 30,85 \\
\hline$a_{2}(50 \%)$ & 29,22 \\
\hline \multicolumn{2}{|c|}{ Formula Bakteri Pemfiksasi N (BPN) } \\
\hline $\mathrm{b}_{0}$ (BPN Kultur Cair) & $26,41 \mathrm{a}$ \\
\hline $\mathrm{b}_{1}(\mathrm{BPN}+$ Carrier Kompos) & $29,72 \mathrm{ab}$ \\
\hline $\mathrm{b}_{2}(\mathrm{BPN}+$ Carrier Azolla) & $28,39 \mathrm{ab}$ \\
\hline $\mathrm{b}_{3}(\mathrm{BPN}+$ Carrier Dedak) & $28,92 \mathrm{ab}$ \\
\hline $\begin{array}{l}\mathrm{b}_{4}(\mathrm{BPN}+\text { Carrier Kompos }+ \\
\text { Azolla) }\end{array}$ & $30,99 \mathrm{~b}$ \\
\hline $\begin{array}{l}\text { b5 (BPN + Carrier Kompos + } \\
\text { Dedak) }\end{array}$ & $31,10 \mathrm{~b}$ \\
\hline $\begin{array}{l}\mathrm{b}_{6}(\mathrm{BPN}+\text { Carrier Dedak + } \\
\text { Azolla) }\end{array}$ & $29,98 \mathrm{ab}$ \\
\hline $\begin{array}{l}\mathrm{b}_{7}(\mathrm{BPN}+\text { Carrier Kompos + } \\
\text { Dedak + Azolla })\end{array}$ & $34,80 \mathrm{c}$ \\
\hline \multicolumn{2}{|c|}{$\begin{aligned} \text { Keterangan: } & \text { Angka-angka yang diikuti huruf yar } \\
& \text { sama pada kolom dan faktor perlakua } \\
& \text { yang sama tidak berbeda nyata pada } \\
& \text { DMRT pada } \alpha=5 \% \text {. }\end{aligned}$} \\
\hline
\end{tabular}

Unsur hara $\mathrm{N}$ memiliki kaitan yang erat terhadap proses pembentukkan klorofil maka dibutuhkan hara nitrogen yang cukup agar kandungan klorofil semakin tinggi. Tanaman dengan unsur $\mathrm{N}$ cukup maka pembentukan klorofilnya optimal yang berdampak pada proses fotosintesis yang berjalan baik (Hall dan Rao, 1981 dalam Ruhnayat, 2007).

Perbedaan kandungan klorofil pada tiap tanaman yang diberi pupuk hayati pemfiksasi $\mathrm{N}$ dalam bahan pembawa diduga karena kadar $\mathrm{N}$ dalam tanah yang meningkat akibat populasi BPN yang meningkat. Kandungan klorofil yang lebih tinggi pada perlakuan BPN dengan bahan pembawa dibandingkan BPN kultur cair sebanding dengan pernyataan Pratanami dan Arum (2017) bahwa mikroba pemfiksasi N berpengaruh terhadap meningkatnya kadar klorofil pada daun bibit sengon yang disebabkan unsur penyusun klorofil terpenuhi.

\subsection{Bobot Gabah Kering Panen (GKP) Per Polybag}

Hasil uji statistika yang dilakukan pada parameter bobot Gabah Kering Panen (GKP) menunjukkan bahwa terdapat interaksi antara dosis Urea dengan formula bakteri pemfiksasi $\mathrm{N}$ dalam bahan pembawa (Tabel 3). Faktor dosis Urea berpengaruh nyata terhadap bobot GKP, sedangkan faktor formula pupuk hayati berpengaruh nyata terhadap parameter bobot GKP. Perlakuan dosis Urea 100\% memiliki hasil lebih tinggi yaitu 29,48 g. Hasil tertinggi pada faktor formula bekteri pemfiksasi $\mathrm{N}$ dalam bahan pembawa terdapat pada perlakuan BPN dalam bahan pembawa kompos, dedak, dan Azolla dengan rata-rata $38,47 \mathrm{~g}$.

Aplikasi pupuk hayati penambat $\mathrm{N}$ dalam bahan pembawa yang berbeda dalam tiap perlakuan menghasilkan bobot GKP yang berbeda pula. Bahan pembawa yang digunakan diduga dapat menyuplai nutrisi yang dibutuhkan BPN untuk berkembang. Hasil gabah yang tinggi pada penelitian ini dapat disebabkan oleh kondisi optimum pertumbuhan tanaman yang dapat tercapai karena eksistensi mikroba yang berasosiasi di sekitar perakaran tanaman (Siarudin dan Suhaendah, 2007). 
Tabel 3 Hasil Analisis Pengaruh Dosis Urea dengan Pupuk Hayati Pemfiksasi N terhadap Bobot GKP Padi Gogo per polibag

\begin{tabular}{|c|c|}
\hline Perlakuan & $\begin{array}{l}\text { Bobot GKP } \\
(\mathrm{g})\end{array}$ \\
\hline \multicolumn{2}{|l|}{ Dosis Urea } \\
\hline $\mathrm{a}_{1}(100 \%)$ & 29,48 \\
\hline$a_{2}(50 \%)$ & 25,60 \\
\hline \multicolumn{2}{|c|}{ Formula Bakteri Pemfiksasi N (BPN) } \\
\hline $\mathrm{b}_{0}$ (BPN Kultur Cair) & $21,33 \mathrm{a}$ \\
\hline $\mathrm{b}_{1}$ (BPN + Carrier Kompos) & $23,78 \mathrm{ab}$ \\
\hline $\mathrm{b}_{2}(\mathrm{BPN}+$ Carrier Azolla) & 28,28 bc \\
\hline $\mathrm{b}_{3}(\mathrm{BPN}+$ Carrier Dedak) & $25,33 \mathrm{abc}$ \\
\hline $\begin{array}{l}\mathrm{b}_{4}(\mathrm{BPN}+\text { Carrier Kompos }+ \\
\text { Azolla) }\end{array}$ & $24,93 \mathrm{abc}$ \\
\hline $\begin{array}{l}\mathrm{b}_{5}(\mathrm{BPN}+\text { Carrier Kompos }+ \\
\text { Dedak) }\end{array}$ & $29,91 \mathrm{c}$ \\
\hline $\begin{array}{l}\mathrm{b}_{6}(\mathrm{BPN}+\text { Carrier Dedak }+ \\
\text { Azolla) }\end{array}$ & $28,30 \mathrm{bc}$ \\
\hline $\begin{array}{l}\mathrm{b}_{7}(\mathrm{BPN}+\text { Carrier Kompos }+ \\
\text { Dedak }+ \text { Azolla })\end{array}$ & $38,47 \mathrm{~d}$ \\
\hline \multicolumn{2}{|c|}{$\begin{array}{l}\text { Angka-angka yang diikuti huruf yang } \\
\text { sama pada kolom dan faktor perlakuan } \\
\text { yang sama tidak berbeda nyata pada uji } \\
\text { DMRT pada } \alpha=5 \% \text {. }\end{array}$} \\
\hline
\end{tabular}

Bakteri pemfikasi $\mathrm{N}$ yang digunakan dalam penelitian ini yaitu Azospirillum dan Azotobacter berperan dalam meningkatkan unsur hara $\mathrm{N}$ yang tersedia bagi tanaman padi gogo. Azospirillum dapat menghasilkan hormon IAA yang berpengaruh terhadap panjang akar padi sehingga dapat mempermudah serapan hara (Lestari dkk., 2007). Semakin banyak koloni bakteri maka kandungan hara $\mathrm{N}$ yang terdapat pada tanaman akan meningkat, hal ini menyebabkan produktivitas tanaman yang meningkat pula.

Penggunaan bahan pembawa pada pupuk hayati pemfiksasi $\mathrm{N}$ menghasilkan bobot GKP yang lebih besar dibandingkan perlakuan tanpa bahan pembawa. Nutrisi yang terkandung pada dedak dalam 100 gram beras yaitu : protein 11,3-14,9\%; karbohidrat 34$62 \%$; serat kasar 7,0-11,4\%; kalsium 30-120\%, pati 13,8\% (Champagne dkk., 1992 dalam Astawan dan Leomitro, 2009). Kandungan hara dalam pupuk Bioposka yaitu C-Organik 9,5413,29\%, K20 0,15-0,34\%, N 0,70-0,99\%, P2O5
0,10-0,19\%, CaO 1,54-2,13\%, Mg 0,25-0,38\%, Mn 429-512 ppm, Cu 11-16 ppm, dan Zn 60-77 ppm (Purwadi, 2013).

Hasil penelitian Setiawati dkk. (2017) menunjukkan bahwa Azolla pinnata sebagai bahan pembawa bakteri Azotobacter sp., Azospirillum sp., Endofitik, dan BPF dapat meningkatkan kandungan $\mathrm{N}$-total sebesar $3,26 \%$ N. Berdasarkan pernyataan ini dapat dilihat bahwa kandungan nutrisi lengkap pada bahan pembawa diduga dapat memfasilitasi mikroba agar dapat hidup dan berkembang biak pada daerah perakaran sehingga ketersediaan hara meningkat pula.

\section{KESIMPULAN}

Berdasarkan hasil dan pembahasan, maka dapat ditarik kesimpulan sebagai berikut:

1. Dosis Urea dengan pupuk hayati penambat $\mathrm{N}$ memberikan interaksi terhadap bobot GKP, namun kedua faktor tersebut tidak menunjukkan interaksi pada parameter jumlah anakan dan kandungan klorofil.

2. Terdapat pengaruh faktor mandiri yaitu faktor pupuk hayati penambat $\mathrm{N}$ yang dapat memberi peningkatan pada parameter jumlah anakan, bobot GKP, dan kandungan klorofil. Faktor dosis urea memiliki pengaruh nyata pada parameter bobot GKP. Perlakuan dosis urea 100\% dan BPN dalam carrier kompos, dedak, dan Azolla memiliki potensi untuk meningkatkan produktivitas tanaman padi gogo.

\section{UCAPAN TERIMA KASIH}

Ucapan terima kasih kepada Universitas Padjadjaran yang telah memberikan dana untuk terlaksananya penelitian ini pada program Riset Kompetensi Dosen Unpad (RKDU) tahun Ajaran 2021. Penelitian ini merupakan bagian dari Penelitian RKDU yang bertidak sebagai ketua peneliti adalah Dr. Dra. Pujawati Suryatmana, M.P. 


\section{DAFTAR PUSTAKA}

Ahmad, A., Susilowati, L.E., dan Arifin, Z. 2015. Uji carrier bakteri pelarut fosfat sebagai agen pupuk hayati. Jurnal Crop Agro :1-9.

Arjjumend, H. 2006. Agro Technology of Organic Farming. New Delhi: Grassroots Institute.

Aryanto, A., Triadiati, dan Sugiyanta. 2015. Pertumbuhan dan produksi padi sawah dan gogo dengan pemberian pupuk hayati berbasis bakteri pemacu tumbuh di tanah masam. Jurnal Ilmu Pertanian Indonesia 20(3):229-235.

Astawan, M., dan Leomitro, A. 2009. Khasiat Whole Grain: Makanan Kaya Serat untuk Hidup Sehat. Gramedia Pustaka Utama. Jakarta.

Cattelan, A.J., P.G. Hartel, dan J.J. Fuhrmann. 1999. Screening for plant growthpromoting rhizobacteria to promote early soybean growth. Soil Sci.Soc.Am.J. 63: 1.670-1.680.

Jumakir, J., dan Endrizal, E. 2019. Respon penambahan pupuk hayati terhadap pertumbuhan dan hasil padi sawah. Jurnal Lahan Suboptimal 8(2):173-180.

Lestari, P., Susilowati, D. N., dan Riyanti, E. I. 2007. Pengaruh hormon asam indol asetat yang dihasilkan Azospirillum sp. terhadap perkembangan akar padi. Jurnal AgroBiogen 3(2):66-72.

Setiawati, M. R., Suryatmana, P., dan Chusnul, A. 2017. Karakteristik Azolla pinnata sebagai pengganti bahan pembawa pupuk hayati padat bakteri penambat N2 dan bakteri pelarut $P$. Soilrens 15(1): 46-52.

Setyamidjaya, D. 1986. Pupuk dan Pemupukan. Pusat Pendidikan dan Latihan Pertanian. Bogor.

Siarudin, M., dan Suhaendah, E. 2007. Uji pengaruh mikoriza dan cuka kayu terhadap pertumbuhan lima provenan sengon di pesemaian. Jurnal Pemuliaan Tanaman Hutan, 1(1): 21-27.
Sirappa, M. P., dan Waas, E. D. 2009. Kajian varietas dan pemupukan terhadap peningkatan hasil padi sawah di dataran Pasahari, Maluku Tengah. Jurnal Pengkajian dan Pengembangan Teknologi Pertanian. 12(1): 79-90.

Supriyo, A., Minarsih, S., \& Prayudi, B. 2014. Efektifitas pemberian pupuk hayati terhadap pertumbuhan dan hasil padi gogo pada tanah kering. Jurnal Agritech 16 (1):1-12.

Pranatami, D. A., dan Arum, S. 2017. Pengaruh pemberian dosis dan frekuensi biofertilizer terhadap kadar klorofil daun bibit sengon (Paraserianthes falcataria (L.) Nielsen). Indonesian Journal of Applied Sciences 7(3): 4450.

Purwadi. 2013. Pupuk bioposka, kompos alami bernilai tinggi. Komunika 7 (10) [Artikel Jurnalisme Sains].

[PUSDATIN] Pusat Data dan Sistem Informasi Pertanian Sekretariat Jenderal Kementerian Pertanian. 2019. Buletin Konsumsi Pangan 10(1): 1221.

Ruhnayat, A. 2007. Penentuan kebutuhan pokok unsur hara $\mathrm{N}, \mathrm{P}, \mathrm{K}$ untuk pertumbuhan tanaman panili (Vanilla planifolia Andrews). Buletin Penelitian Tanaman Rempah dan Obat 18(1): 49-59.

Yoshida, S. 1981. Fundamental of Rice Crop Science. International Rice Research Institute: Philippines. 